\title{
Constitutional Development on Mineral and Coal Governance in Indonesia
}

\author{
Sinta Ana Pramita ${ }^{1}$, I Gusti Ayu Ketut Rachmi Handayani ${ }^{2}$, Lego Karjoko ${ }^{3}$ \\ ${ }^{123}$ Universitas Sebelas Maret \\ Surakarta, Indonesia \\ sintaanapramita@student.uns.ac.id
}

\begin{abstract}
This study aims to determine the constitutionality development on mineral and coal governance based on constitutions. Normative legal research with statutory and conceptual approaches is carried out in this study. The findings are in line with mineral and coal governance on Government Regulation (PP) Number 1, 2017, on the fourth amendment on Government Regulation (PP) Number 23, 2010 concerning the operational activity of mineral and coal mining. Contradicts to Law of Republic Indonesia Number 4, 2004 concerning Mineral and Coal mining, this is related to whether or not a mineral and coal governance in Indonesia has met the constitutions based. Carryover requirements as a formality in Mineral and Coal Law formation has a potential problem. Mineral and Coal Law did not meet the carry-over procedure following Law of Republic Indonesia Number 12, 2011 concerning legislation making. Besides, the Central Leadership Council (DPP) did not play a role in the Law-making process. Those factors occurred in the Law-making process, which the problematic legal norms to appear in their formation and caused implementation problems. The problematic legal norms are (1) nonoperational legal norms in mineral and coal law (2) conflict of norms in Mineral and Coal Law and Regional Government Law.
\end{abstract}

Keywords- Development, Constitutions, Mineral and Coal Governance.

\section{INTRODUCTION}

The constitution of a country is defined as the highest legal norm codified as a written document. The existence of a constitution in the Republic of Indonesia is crucial and considered nationalistic as it is in other countries. Constitutions regulate all aspects in achieving state objectives and national interests. The interest and welfare of the people of republic Indonesia are also included in aspects regulated in the constitution of Republic Indonesia. The Constitution of Republic Indonesia covers the role in regulating administrative, political, social, economic, and cultural life issues stated in articles 32, 33, and 34. The role is different from the constitution in other states. Jimly Asshiddiqie categorized the Law of the Republic of Indonesia as the economic and social constitution.[1]

The Constitution of the Republic of Indonesia is constitutionally stipulated as the highest legal constitution in Indonesia. It is a fundamental law in Indonesia applied to running state administration systems and interpreted as the general basis of other rules. Moreover, since mining activities are being used as a national development sector and the prosperity of the people, it is necessary to have a constitutional arrangement that provides guarantees and attention to the treatment of mining activities. It is written in a book entitled "Advances in Productive, Safe, and Responsible Coal Mining 1st Edition" that stated, "improvement in productive, safe and responsible coal mining include the latest advancement in coal mining technology and practices, thus guarantees and protection of natural resources are needed to be sustainable."[2]

By understanding aspects of downstream activities under the constitutional mandate, the following task of the State is consistency in directing natural resource management policies, especially mining activities as aspired by the constitution.[3] The main issue with mining guarantees is the extent to which natural resource management can provide and impact the greatest prosperity of the people. However, the mining constitution is considered unconstitutional.

The unconstitutionality of mineral and coal governance constitutional development in Indonesia is regulated in the Law of Republic Indonesia, article 33 (4), "the organization of the national economy shall be conducted based on economic democracy upholding the principles of togetherness, efficiency with justice, continuity, environmental perspective, self-sufficiency, and keeping a balance in the progress and unity of the national economy." Therefore, private ownership must be understood relatively, which means it is not $100 \%$ controlled by the State. Ownership rights need recognition from others for the rights owned by others.[4] In shared control by the State, the most important thing is how to ensure that the State remains decisive in the decision-making process on determining policies in the business entity concerned.

According to the Constitutional Court, divestment or privatization of the Government's 
share ownership in the relevant state-owned enterprise cannot be considered a conflict with Article 33 of the 1945 Constitution.

The conflict of The regulation of the Minister of Energy and Mineral Resources of the Republic of Indonesia Number 5 and 6, 2017 with the Law of the Republic Indonesia Number 4, 2009 concerning Mineral and coal mining respond the Mineral and coal governance in Government Regulation Number 1, 2017 in Fourth Amendment of the Government Regulation Number 23, 2010 about the operational activity of mineral and coal mining. With this conflict, studies and discussions are needed to provide guarantees and certainty for the existence of the environment in mining activities, recognizing that the wealth of Republic Indonesia is given for future generations.[5]

The researchers limit this study to the constitutional development of mineral and coal governance in Indonesia regarding the constitutional status of mineral and coal constitution or the constitutional Mineral and coal governance. Unconstitutionality and conflict in the source of Law become the basis of necessity for certainty to provide guarantees in regulating mining activities.

\section{RESEARCH METHOD}

This research used a normative juridical method with a statutory approach or a conceptual approach in which the Law is the object of research. This approach is regularly used to analyze conflict norms.[6] This study analyzed article 33 of Law of the Republic of Indonesia 1945, Mineral and coal governance in Government Regulation (PP) Number 1, 2017 concerning the fourth amendment of Government Regulation (PP) Number 23, 2010, about "the mineral and coal mining operational activity". The researchers involved those legal sources since responses have emerged that Government Regulation concerning Mineral and coal in Minister of Energy and Mineral Resources of the Republic of Indonesia Number 5 and 6, 2017 are contrary to Law Number 4, 2009 concerning "Mineral and coal mining".

\section{FINDINGS AND DISCUSSION}

Constitutions exist as fundamental principles and norms that govern the power system and how the system works to achieve common goals in an organization.[7] When the organization recognizes as a State, the constitutions mentioned here consist of how the power of a state is used to achieve the State's objectives. The existence of a Government in a constitution becomes activities organized by and on behalf of the people. The Government further related to several restrictions on the State constitution in ensuring the power used appropriately. The guarantee and protection of the people's rights are the results of good government power.

The Government's power in ensuring and protecting people's rights reflected on the role and the massive contribution of the Government in the management of natural resources, specifically the mining activity. Mining activity needs special attention due to the justice in its management and utilization has not met the requirements. Natural resources have great potential for supporting nation-building and fulfillment of people's prosperity and welfare. The Government also needs to arrange the best environmental policy as an integral part of nation-building.[8] The Law of the Republic of Indonesia 1945, article 33 (3) emphasized that the land, waters, and natural resources within shall be under the powers of the State and shall be used to the most significant benefit of the people. When everyone utilizes a limited number of natural resources, individuals have the rationality to use them intensively, which leads to the decreasing of natural resources available, and all parties are at a loss.[9] The example is in the forest sector that has been run into degradation and deforestation, leading to open access forests.[10]

Legal sources concerning the mining activity in Indonesia run unconstitutionally and has the conflict between legal sources. The conflict was proven by the Minister of Energy and Mineral Resources of the Republic of Indonesia Number 5 and 6, 2017, which contradicts the Republic of Indonesia Number 4, 2009, concerning "Mineral and coal mining". Besides, it is also related to article 33 of Law of the Republic of Indonesia 1945 and mineral and coal governance on Government Regulation (PP) Number 1, 2017, on the fourth amendment on Government Regulation (PP) Number 23, 2010 concerning the "operational activity of mineral and coal mining". The life of more than 100 million people lay on small-scale mining activity.[11]

The Law of Mineral and coal has a potential problem in the way of its formation formality. The Law did not involve the carry-over requirements as mentioned in Law Number 12, 2011 concerning "Legislation making", includes the potential problem of the absence of the Central Leadership Council (DPP) in its making. The House of Representatives of the Republic of Indonesia (DPR) proposed the bill concerning the amendment of Law Number 4, 2009, about "Mineral and coal mining" on the national legislative program priority list on February 2, 2015. Commission VII (energy, Mineral Resources, Research and Technology, Environmental Affairs) of DPR proposed the mineral and coal mining bill that substances are processing and refining the minerals in the 
country. In Law Number 3, 2020, concerning the amendment of Law Number 4, 2009 about "mineral and coal mining" will be sued in the Constitutional Court. According to Law Number 8, 2011 concerning "Constitutional Court", testing of the Law can be carried out on the Law's material and the formal or procedure for forming the regulation.[12]

The Government has issued the Law concerning mining business activity, especially Mineral and coal. Article 33 (3) of the Republic of Indonesia 1945 's Law underscores that the State shall control the land and waters and natural resources contained and exploited for the best prosperity of the people is the basic regulation.[13] Law Number 11, 1967 on introductory mining provisions is the first Law in Indonesia, but the Law of Basic Provisions of Mining has been replaced with Law Number 4, 2009 concerning "mineral and coal mining" since February 2009. In the following years, Government Regulations, Ministerial Regulations, Director-General Regulations, and Regional Regulations, which are implementing Law Number 11, 1967, have gradually changed. With the strategic issues regulated in Law Number 4, 2009 regarding "the increase in valueadded related to the downstream mining industry," implementing regulations are made in Government Regulations and Regulations of the Minister of Energy and Mineral Resources.

When the Government Regulation Number 1, 2017 and the regulation of the Minister of Energy and Mineral Resources of the Republic of Indonesia Number 5 and 6, 2017 are legalized, the discussion arose from the public regarding the appropriateness of those Laws with Law Number 4, 2009 concerning "Mineral and coal mining". The discussions were struggling in the substance of Government Regulation Number 1, 2017. The discussions give rise to various arguments. Those reasons impact social conflict[14] because the legal system is a peculiar form of social life.[15] In this case, awareness about the main legal problem behind Mineral and coal regulation is essential.

Regarding the controversy over the Mineral and Coal Law, the revision of the Mineral and coal law is still not constitutionally based because there are several problems, including:

1) Regarding the loss of the word purifying in Article 112C (4), Government Regulation (PP) Number 1, 2017, Law Number 4, 2009 confirmed "the mandate concerning oil and gas downstream activities". Law Number 4 , 2009 Article 102 and 103 required "enhancing the value-added of mineral and coal resources in processing and purification activities on domestic mine products". However, Article 112C (4) confirmed that
"Holders of IUP Production Operation, mentioned in number 2 , conduct mineral and coal mining and conduct mineral processing and export its product in specific numbers." Due to the absence of the word purifying after the word process in Article 112C number 4 in PP Number 1 of 2017, it can be said to eliminate one obligation that the holders of IUP or IUPK must fulfill. Law Number 4, 2009 stated that "no single word process stands alone, always side-by-side with purifying." This has violated articles 102 and 103 (1).

2) The form of sub-delegation of the regulation on increasing value-added from Law Number 4, 2009 against the Minister of Energy and Mineral Resources. Article 112C point 5 of the Government Regulation Number 1, 2017 emphasized "details on purifying and processing, the minimum amount of purifying and processing, and export regulated in Minister Regulation." Based on this Article, provisions regarding the implementation of processing and refining, minimum limits for processing and purification, and exports are regulated using a Ministerial Regulation instrument. Regarding the increase in value-added as referred to in Article $112 \mathrm{C}$ number 5, it used Government Regulation, not the Minister of Energy and Mineral Resources Regulation. It is regulated in Article 103 (3) Law Number 4, 2009 that stated further provisions concerning the increase of the value-add as stated in Article 102 and processing and purification as stated in paragraph (2) are to be regulated in Government Regulation.

3) The process and steps in making the Regulation of the Minister of Energy and Mineral Resources of the Republic of Indonesia. When Government Regulation Number 1, 2017, and the Regulation of the Minister of Energy and Mineral Resources of the Republic of Indonesia Number 6 and 7, 2017, were issued on January 11, 2017, these three Legal instruments were issued the same way. This study analyzed the issue with Law Number 12, 2011 concerning Legislation Making from the legal making. The Preamble to the Regulation of the Minister of Energy and Mineral Resources Number 6, 2017, states that the legal basis is from the Minister of Energy and Mineral Resources Number 5 of 2017. Then, the Preamble to the Regulation of the Minister of Energy and Mineral Resources Number 5 of 2017 stated the legal basis for Government Regulation Number 1, 2017.

4) Regarding the grant for mineral and coal export permit on the Regulation of Minister 
of Energy and Mineral Resources Number 5, 2017, concerning "the increase in valueadded of minerals through domestic mineral processing and refining activities" and the Regulation of the Minister of Energy and Mineral Resources Number 6 of 2017 about the "procedures and requirements for granting the export permit, essentially allowing mining actors to export with specific requirements." Legally, those Laws are contrary to Article 103 of Mineral and Coal Law that required processing and refining of domestic mining production. Constitutional Court Decision Number 10/PUU-XII/2014 is fundamental for this legal basis. This confirms that there are no multiple interpretations and constitutional contradictions regarding domestic processing and purifying obligations.

However, several legal steps concerning the unconstitutionality of mineral and coal utilization in Article 103 of Mineral and Coal Law that said the holder of a Production Operations IUP and an IUPK is obligated to undertake processing and purification activities on domestic mine products. Furthermore, Article 39 of "Mineral and Coal Law" emphasized that "when IUP exploration is upgraded to an IUP Production Operation, processing, and purifying location must be. When mining permit holders (IUP) or special mining permit holders (IUPK) upgraded from exploration special mining permit holders to Production Operation Special Mining Permit holders, they need to do the processing and purification activities in the domestic area." Issuing IUPK as regulated by Law Number 4, 2009, shows a difference with IUPK, which replaces KK as happened to PT. FI and PT AMNT. It should be analyzed where the IUPK's legal foundation came from.

\section{CONCLUSION}

The governance of Mineral and coal in Government Regulation Number 1, 2017 concerning the Fourth Amendment on Government Regulation Number 23, 2010 about the operational activity of mineral and coal mining conflicted with Law Number 4, 2009 on Mineral and Coal mining. This is related to the constitutionality of Mineral and Coal in Indonesia that is questionable. As stated in the Mineral and Coal Law, the potential problems occur in its formation in carry-over requirements. The mineral and coal law found out to be neglected the carry-over procedure as stated in Law Number 12, 2011 concerning legislation making. The absence of the Central Leadership Council (DPP) in legislation-making influences the missing requirements in the law-making process, leading to implementation problems.

\section{REFERENCES}

[1] M. Roestamy, "Model Land Supply for Land Bank to House Application Martin," Bestuur, vol. 7, no. 2, 2019.

[2] A. Jumari, "Potensi Pelanggaran Pengelolaan Limbah Bahan Berbahaya dan Beracun," J. Best., vol. 7, no. 2, 2019.

[3] Yusriando, "Konstruksi Sistem Jaminan Sosial Nasional Bidang Kesehatan Yusriando," Bestuur, vol. 7, no. 2, 2019.

[4] U. K. Mishra and A. Negi, "Transgender and the Right to Employment in India: Analysing the Trajectories of Discrimination," Bestuur, vol. 9, no. 1, pp. 34-43, 2021.

[5] L. C. Lintang, Adriano Martufi, and J.W. Ouwerker, "The Alternative Concepts of Blasphemy Law in Indonesia: Legal Comparison with Ireland and Canada," Bestuur, vol. 8, no. 2, pp. 121-128, 2020.

[6] S. R. Novikasari, D. Q. Ly, and K. Gershaneck, "Taxing Micro, Small and Medium Enterprises in Yogyakarta: Regulation and Compliance," Bestuur, vol. 9, no. 1, 2021.

[7] M. A. Mohd Sani and D. D. Abdul Hamed Shah, "Freedom of Religious Expression in Malaysia," J. Int. Stud., pp. 33-50, 2020.

[8] S. A. Estikomah, "Aspek Hukum Import Sampah Plastik," Bestuur, vol. 7, no. 2, p. 41, 2019.

[9] A. A. Hamzana, "Pelaksanaan Standarisasi Pelayanan Pariwisata Halal dalam Pengembangan Pariwisata di Nusa Tenggara Barat," Pena Justisia Media Komun. dan Kaji. Huk., vol. 17, no. 2, pp. 1-16, 2018.

[10] B. Prasetyo, I. G. A. K. R. Handayani, A. Sulistyono, and L. Karjoko, "Legal framework for social security state civil apparatus," Int. J. Adv. Sci. Technol., vol. 28, no. 20, pp. 310-313, 2019.

[11] I. Gusti Ayu Ketut Rachmi Handayani, G. Gunarto, A. Mashdurohatun, I. Gusti Putu Diva Awatara, and F. U. Najicha, "Politic of legislation in Indonesia about forestry and the mining activity permit in the forest area of environmental justice," Journal of Engineering and Applied Sciences, vol. 13, no. 6. pp. 1430-1435, 2018.

[12] A. K. Jaelani, I. G. A. K. R. Handayani, and L. Karjoko, "Development of tourism based on geographic indication towards to welfare state," Int. J. Adv. Sci. Technol., vol. 29, no. 3 Special Issue, pp. 1227-1234, 2020.

[13] R. D. Luthviati, "The Role of Local Governments in the Defense of Leading Products Resti," J. Best., vol. 8, no. 2, pp. 121-128, 2020.

[14] Yuliandri, G. A. K. R. Handayani, T. Prasetyo, K. Seregig, and H. Tegnan, "Retributive justice theory and the application of the principle of sentencing 
proportionality in Indonesia," J. Leg. Ethical Regul. Issues, vol. 21, no. 4, pp. 1-8, 2018.

[15] I. G. A. K. R. Handayani, H. Glaser, S. Monteiro, E. D. Kusumawati, A. K. Jaelani, and F. U. Najicha, "Water availability in the framework of environmental justice: reconstruction of municipal waterworks (pdam) regulations," Int. J. Business, Econ. Law, Vol. 20, Issue 4 2019, vol. 20, no. 4, pp. 51-55, 2019.

[16] I. Iswantoro, "Strategy and Management of Dispute Resolution, Land Conflicts at the Land Office of Sleman Regency," J. Hum. Rights, Cult. Leg. Syst., vol. 1, no. 1, pp. 117, 2021.

[17] A. Ma, "Legal Aspects of Environment in Indonesia: an Efforts to Prevent Environmental Damage and Pollution," $J$. Hum. Rights, Cult. Leg. Syst., vol. 1, no. 1, pp. 18-30, 2021.

[18] A. K. Jaelani and R. D. Luthviati, "The Crime Of Damage After the Constitutional Court' s Decision Number 76 / PUU-XV / 2017," J. Hum. Rights, Cult. Leg. Syst., vol. 1, no. 1, pp. 31-41, 2021.

[19] R. Res, "Implementation of Parate Executie Object of Liability Juridical Overview of Mortgage," J. Hum. Rights, Cult. Leg. Syst., vol. 1, no. 1, pp. 42-53, 2021.

[20] Syahlan, "Effective and Efficient Synchronization in Harmonization of Regulations Indonesia," J. Hum. Rights, Cult. Leg. Syst., vol. 1, no. 1, pp. 54-70, 2021.

[21] R. I. Ichlas, "Questioning the Independence of Media Coverage in the 2019 Elections," $J$. Best., vol. 8, no. 1, 2020.

[22] W. N. Hanum, "Setting of Earth Oil Management in Old Wells Based on the Principle Social Justice," Bestuur, vol. 8, no. 2, p. 70, 2020.

[23] K. Intaniasari, "Gross Split Contract Framework Regulation on the Caring for People," Bestuur, vol. 8, no. 2, p. 96, 2020. 